\title{
The Standard Output of Forest Index - an Indicator of Site Quality
}

\author{
Endre SCHIBERNA* \\ Forest Research Institute, National Agricultural Research and Innovation Centre, Sopron, Hungary
}

\begin{abstract}
The Standard Output of Forest Index (SOFI) describes the ability of forests to produce financial value from wood production based on the standardized monetary value of the mean annual increment of the potential final harvest relative to a reference forest type. It can be applied on regions where the forests can be classified into major tree species or species groups and into site classes. The potential volume of final wood harvest is estimated through yield tables. Using the share of lowquality and high-quality wood product groups in the final harvest, and their respective standardized price, the output value of the final harvest is expressed and then divided by the rotation age. This standardized output is compared to a reference forest type identified by its tree species and site class, and multiplied by 10 points. The SOFI of the reference forest, therefore, is 10 , while higher values represent higher potential output and smaller values represent smaller potential output. With the necessary modifications, the SOFI can be applied to uneven-age forests as well. It can primarily be used to describe and compare the financial output potential of larger forest areas.
\end{abstract}

Site index / site classes / forest productivity / wood quality / SOFI / forest economics

Kivonat - Erdészeti termelési érték index - a termőhelyi potenciál mutatója. Az erdészeti termelési érték index (SOFI) az erdők fatermesztésből származó pénzérték termelő képességét jellemzi a korszaki átlagnövedék standardizált pénzügyi értékének kifejezésével és egy meghatározott referencia erdőtípushoz történő viszonyításával. Olyan földrajzi régiókban alkalmazhatók, ahol az erdők főbb fafajok, illetve fafajcsoportok és fatermési osztályok szerinti csoportokba sorolhatók. A potenciális véghasználati fahozam fatermési táblák alapján becsülhető. Az alacsony és magas minőségü fatermékek véghasználati hozamon belüli arányára és azok standardizált pénzértékére alapozva a véghasználati kibocsátási érték kifejezhető, amelyt a vágáskorral osztunk. Ez a standardizált termelési érték viszonyítandó egy fafaj és fatermési osztály által meghatározott referencia erdő értékéhez, és a könnyeb megjeleníthetőség érdekében 10 ponttal szorozzuk. Ezáltal a referencia-erdő SOFI értéke 10, míg a magasabb értékek magasabb potenciális termelési értéket, az alacsonyabb értékek alacsonyabb potenciális termelési értéket jelentenek. Megfelelő módosításokkal a SOFI többkorú erdőkre is alkalmazható. Elsősorban nagyterületü erdők pénzügyi kibocsátási potenciáljának leírására és összehasonlítására használható. Elsősorban nagyobb erdőterületek potenciális kibocsátásának jellemzésére alkalmazható.

termőhelyi index / fatermési osztály / termőhely jósága / termőképesség / fa minősége / SOFI / erdészeti ökonómia

\footnotetext{
* Corresponding author: se@erti.hu; H-9400 SOPRON, Paprét 17, Hungary
} 


\section{INTRODUCTION}

This paper introduces the Standard Output of Forest Index (SOFI) by presenting its definition, calculation method, and the rationale of application. The aim of the introduction of the SOFI is to provide an index which can represent the extent to which a forest site is suitable for wood production. The index measures both the quantity and quality of a site relative to other sites by providing a financial basis comparison over various tree species and forest types.

The ability of a forest site to produce wood is generally understood as its site quality. Better site quality results in higher volume of wood in a given period of time, which can be expressed through standing volume, total wood production, or other features. Site index is commonly used to describe site quality, which is the height of the dominant trees at a reference age. The assumption that height growth strongly correlates with the increment of the growing stock has been used since as early as the end of $19^{\text {th }}$ century (Baur 1881) to describe forest growth and to predict future wood production potential.

If the height-to-age relationship of a tree species or forest type is known, the site index can be calculated at any age on the growth curve's domain. The site index can be grouped into site classes in order to divide the height-to-age continuum into distinct categories, simplifying the description of site quality considerably. Site classes can be characterized by their growing stock, stem number, basal area, annual increment, and mean diameter as the function of age of the tree stand. Such datasets can be found in yield tables. Although the fundamental assumptions of such yield tables and their application on large regions has been challenged and proved to be inadequate under certain management regimes (Skovsgaard - Vanclay 2008), they are widely used in practice.

Site quality is the interplay of forest site properties and tree stand type. The forest site can be described by its climate (the combination of temperature, precipitation, and other factors), hydrological properties, soil (type, depth, texture, and nutrition content), while the most important tree stand characteristics are tree species composition (provenance may also be considered) and establishment method (seed or coppice, spacing). Therefore, the site index can only be used for comparison within tree species or tree species groups.

This study does not directly address possible site condition shifts. Should these occur in over the long term, their effects on future growth potential need to be considered. Detectable increase in the forest growth rate was reported in some areas (Somogyi 2008, Pretzsch 2014), while forest cover extinction is projected at the xeric limits of forests in other areas (Mátyás et al. 2014). Climate change is one of the large-scale causes of such changes, which can be coupled with changes in hydrological conditions (Csáki et al. 2014, Moricz et al. 2016).

The advantage of the site index is that tree stand height is less influenced by forest management interventions, e.g. thinning, than by other stand characteristics, e.g. number of stems, diameter etc. However, the application of the site index is confined to situations when forests are even-aged and their age can be determined by samples or from planting records. These latter obstacles can easily be tackled in areas with long traditions of forestry and forest cultivation, as forest inventories in such areas tend to possess over $90 \%$ coverage (MacDicken et al. 2015). Other areas require alternative methods based on features other than age.

In forests of differing tree species, comparisons of wood productivity can be based upon mean annual increment (MAI) at a reference age representing the typical rotation age of the respective tree species in the described region. Increment is normally measured in volume (cubic meters), but a more accurate comparison can be achieved if the increment is expressed in dry matter weight (tons). Since the dry weight of wood strongly correlates with its carbon content (Lamolm - Savidge 2003), the dry weight of MAI is not only an indicator of wood production capacity, one that allows for cross-species comparison, but can also express the aboveground carbon sequestration capacity of forests. (Gallaun et al. 2010) 
The above approaches to site quality imply that larger natural output in volume or dry matter under the same period of time contributes to higher financial output. To describe and compare the financial potential of forests as an alternative understanding of site quality entails considering the market value of wood products. Based on growth information and the forest management regime, the financial flows for a given time period can be modelled and used to calculate economic properties such as income, added value, margin or profit, etc. However, these calculations are either applied in regions of homogenous forest types under similar forest management regimes and are based on necessary simplifying assumptions (Pandey et al. 2010), or they need to gather exhaustive amounts of data and build large numbers of models. The data collection method determines the comparability of economic features and limits large scale analysis (Sekot et al. 2011, Vrolijk et al. 2016).

Site quality is a feature of a specific site, and its indicators express its production capability, which is an important component of a site's land value. However, this feature should not be treated as a single component, as it is, to a great extent, influenced by the utilization forms, forest management regimes, production risks, organizational arrangements, management objectives, etc. (Hartebrodt 2007, Posavec 2017, Beljan et al. 2018).

\section{THE STANDARD OUTPUT OF FORESTRY INDEX}

\subsection{Aim, principles and definition}

The aim of the SOFI is to provide a site quality index that considers the potential quantity and quality of wood production and allows for comparisons both within and across tree species.

The principles of the index design:

- As long as the representative power of the index is not seriously corrupted, a simple calculation method takes precedence over accuracy.

- Meant to be an indicator of the potential financial performance of forests, rather than an exact economic variable.

- Describes the variability of forest type and forest site combinations rather than the differences in the financial value of wood in different regions.

Definition: the Standard Output of Forest Index describes the ability of forests to produce financial value through wood production based on the standardized monetary value of the mean annual increment of the final harvest relative to a reference forest type.

\subsection{Calculation method and data source}

\section{Step 1: Forming forest categories}

Within a defined geographical area where the SOFI will be employed, forests shall be categorized according to major tree species, species groups, or sub-species categories (e.g. selections or provenances) for which growth and wood price data are available. Groups shall be formed with due consideration of their share in forest cover and the availability of the data specified in the next steps.

\section{Step 2: Determining final harvest volume and rotation age}

There is no restriction on how to determine potential final harvest volume and final harvest age, but yield tables based on site classes are the most commonly available tools. If available, silviculture models can also be a good data source. Theoretically, rotation age can be determined at the forest plot level, but this data is unlikely to be available in young forest stands. Therefore, it is best to unify rotation age on the whole geographical area of application 
(or at least at the regional level) by tree species and site index classes, which represent the best financial interest of the forest owner/manager under the relevant legal framework.

\section{Step 3: Determining the share of high-quality and low-quality wood product groups}

The calculation of the SOFI requires the proportion of low-quality wood products be known. There is no clear distinction between low quality and high-quality wood products. Firewood and pulp and paper wood typify the former, while saw logs and veneer logs belong to the latter. In general, there are usually no quality requirements for low-quality products other than they consist of healthy solid wood, and that they are measured in stockpiles. High-quality products are inspected against quality requirements and measured piece by piece. If in doubt as to where a specific wood product belongs, price is decisive. The definition of wood products and their grouping may follow national or international standards, but it shall correspond to the wood product classification applied in wood price data sources described in Step 4. The share of the wood product groups shall represent averages of a 5-10-year period.

Step 4: Selecting representative wood products for the high-and low-quality groups and standardizing their monetary value

For each of the high and low-quality product groups, a representative product that has the highest total output value within the respective product group shall be selected. The value of wood products shall be expressed in monetary terms, usually those stated in controlled markets such as commodity exchanges, farm accountancy data networks, or national statistics; however, in the absence of these, individual surveys can become possible sources of price information. The data source, however, is suitable only if prices of the most important wood products can be obtained for a time period no shorter than five years. In the calculation of the SOFI, the 5-10 year average of these prices shall be used.

\section{Step 5: Calculating and indexing to a selected forest type}

The standard output for each forest category shall be calculated according to eq. 1 . Final harvest volume is multiplied by the weighted average value of wood and divided by the rotation age. As an alternative, eq. 2 can be applied in cases when rotation age and the final harvest volume are unavailable, but the mean annual increment can be estimated.

One of the forest categories shall be designated to serve as the basis of indexing. This reference forest shall cover a relatively large area and will be selected from around the middle of the standard output spectrum. For a simpler presentation, the proportion of the standard output of the specific forest category to the reference category is multiplied by 10 points. Thus, the unit of SOFI is 'points'.

Where:

$$
\begin{aligned}
& \mathrm{SOF}_{x}=\frac{\left[S V_{L Q x} \cdot \mathrm{LQ} \%_{x}+S V_{H Q x}\left(1-\mathrm{LQ} \%_{x}\right)\right] \mathrm{Q}_{x}}{R_{x}} \\
& \mathrm{SOF}_{x}=\overline{S V_{x}} \cdot \mathrm{MAI}_{R x} \\
& \mathrm{SOFI}_{x}=\frac{\mathrm{SOF}_{x}}{\mathrm{SOF}_{r e f}} \cdot 10
\end{aligned}
$$

$x$ :

ref:

SOF:

SOFI:

$\mathrm{SV}_{\mathrm{LQ}} ; \mathrm{SV}_{\mathrm{HQ}}$ : standard value of the representative wood product in the low-quality and highquality forest product groups LQ\%: share of low-quality forest product group in the final harvest

Q: $\quad$ potential standing volume of wood at final harvest 
R: $\quad$ rotation age

MAI $_{\mathrm{R}}$ mean annual increment of the potential final harvest

$\overline{S V}: \quad$ weighted average value of the low- and high-quality forest product groups

\section{Step 6: Application to the forest area}

The SOFI can be applied to forest areas where species composition and site classes (or other parameters that have been used for classification at Step 1) are known. The minimum level of application corresponds to that of the natural parameters, which is, most commonly, the forest sub-compartment; however, this can be aggregated to larger areas as well.

\section{CONSIDERATION OF DESIGN ALTERNATIVES}

The actual financial performance of a forest depends on the harvested volume, the market value of its products, and the production costs, which includes harvesting, (re-)establishment, planning, supervision, and other administrative tasks. Surveying relevant data becomes a demanding task if the actual financial performance is to be presented or used in an analysis. This is especially pertinent in larger geographical areas with varied forest stand types and forestry practices.

This is also valid if the potential economic performance needs to be taken into account. In this case, potential harvest volume can be interpreted as the allowable cut within the time horizon of the study based on the current state of the forests depending on their age, volume, stocking, health status, management objectives, conservation, and other limitations. Another option is to make estimations on the future potential based on the combinations of the site conditions and tree stand type. Going even further, if the current tree stand is, for some reason, unable to utilize the full production potential of the site due to factors like bad species in the past, then an alternative forest type with highest potential production can also be used for the calculation.

The SOFI is meant to represent the suitability of the forest area to produce financial value based on the current site and forest type combinations. It aims at considerably simplifying data collection, modelling, and calculation tasks by reducing the necessary amount of data, while providing a good approximation of the potential financial performance of a study area. This is why the most schematic method was incorporated into the calculation method from among the options described above.

Final harvest volume represents a forest's wood production capacity. Excluding the premature wood production renders the SOFI biased because the share of premature wood in total wood production varies significantly in the different tree species groups, as observed in Table 1.

Simply replacing final harvest volume with total wood production would also raise concerns regarding financial valuation as thinnings produce wood products of lower quality and smaller dimensions compared to final harvest products. Extending the calculations by incorporating the estimation of the monetary value of the premature harvests would require further estimations of the share of wood product groups. The dilemma of whether the approximation of the output should be based on a more detailed calculation, or the calculation should be kept the simplest possible, has been decided in two arguments. First, one of the principles of the SOFI is to avoid detailed modelling and obtain only the smallest number of absolutely necessary factors. Second, timber harvests are generally not subject to market circumstances only, but to non-economic considerations as well (Kilham et al. 2019). This is even more applicable to premature harvests because their expected profit is smaller than that of the final harvest; therefore, their contribution to the 'output potential' is questionable. 
Table 1. The share of the final harvest volume in the total wood production of selected species based on their yield tables (Source of data: Béky 1981, Keserü and Rédei 2012, Rédei et al. 2019)

\begin{tabular}{|c|c|c|c|c|c|c|c|}
\hline \multirow{2}{*}{$\begin{array}{l}\text { Tree } \\
\text { species }\end{array}$} & \multirow{2}{*}{ Wood production category } & \multicolumn{6}{|c|}{ Site classes } \\
\hline & & I. & II. & III. & IV. & $\mathrm{V}$. & VI. \\
\hline \multirow[t]{3}{*}{ Oak } & Total wood production at age $100\left(\mathrm{~m}^{3} / \mathrm{ha}\right)$ & 1056 & 905 & 762 & 630 & 509 & 394 \\
\hline & Final harvest volume at age $100\left(\mathrm{~m}^{3} / \mathrm{ha}\right)$ & 595 & 510 & 432 & 357 & 288 & 222 \\
\hline & $\begin{array}{l}\text { Proportion of final harvest } \\
\text { in the total production }(\%)\end{array}$ & 56.3 & 56.4 & 56.7 & 56.7 & 56.6 & 56.3 \\
\hline \multirow{3}{*}{$\begin{array}{l}\text { Black } \\
\text { locust }\end{array}$} & Total wood production at age $30\left(\mathrm{~m}^{3} / \mathrm{ha}\right)$ & 463 & 387 & 316 & 252 & 195 & 173 \\
\hline & Final harvest volume at age $30\left(\mathrm{~m}^{3} / \mathrm{ha}\right)$ & 304 & 252 & 204 & 162 & 124 & 107 \\
\hline & $\begin{array}{l}\text { Proportion of final harvest } \\
\text { in the total production }(\%)\end{array}$ & 65.7 & 65.1 & 64.6 & 64.3 & 63.6 & 61.8 \\
\hline \multirow{3}{*}{$\begin{array}{l}\text { Hybrid } \\
\text { poplar }\end{array}$} & Total wood production at age $20\left(\mathrm{~m}^{3} / \mathrm{ha}\right)$ & 412 & 349 & 298 & 247 & 201 & 163 \\
\hline & Final harvest volume at age $20\left(\mathrm{~m}^{3} / \mathrm{ha}\right)$ & 341 & 276 & 228 & 187 & 151 & 121 \\
\hline & $\begin{array}{l}\text { Proportion of final harvest } \\
\text { in the total production }(\%)\end{array}$ & 82.8 & 79.1 & 76.5 & 75.7 & 75.1 & 74.2 \\
\hline
\end{tabular}

It is, therefore, left to the user to decide whether to use the original form of the SOFI or to modify it according to the available data. One alternative modification is presented in eq.4, which would adequately reflect the forestry practice in hardwood regions, but would not necessarily be suitable elsewhere. Eq.4 is a modification of eq.1 by adding the premature harvest potential at the standard value of low-quality wood products, as if $100 \%$ of the premature wood harvest belonged to the low-quality product group.

$$
\mathrm{SOF}_{x}=\frac{\left[S V_{L Q x} \cdot \mathrm{LQ} \%_{x}+S V_{H Q x}\left(1-\mathrm{LQ} \%_{x}\right)\right] \mathrm{Q}_{F H x}+S V_{L Q x} \cdot \mathrm{Q}_{P H x}}{R_{x}}
$$

Where symbols are the same as at eq.1, except:

$\mathrm{Q}_{F H x}$ : Volume of final harvest

$\mathrm{Q}_{P H x}$ : Volume of premature harvest

While natural aspects such as final harvest volume represent the specific site, the economic layer (distribution of wood products and prices) is standardized. This is justified by the circumstance that the primary aim of SOFI is to represent forest capability. Thus, the effects of the regional differences in the economy (i.e. the wood industry and other related sectors) and the customs of direct household consumption should be excluded. This is the reason for calculating with mid-term or long-term average wood product distribution and prices. These factors are unified for the whole study area.

Although forests can produce a large variety of products and services, wood products remain one of the most important sources of income (Sisak et al. 2016). Among various factors, the actual wood product distribution of a specific final harvest depends on tree quality, tree dimensions, market demand, and forest manager preferences (e.g. own consumption needs). To tackle this problem, wood products are grouped into low-quality and high-quality groups, thereby eliminating the effects of minor changes. Calculating with the average product distribution over a 5-10-year period levels short-term volatility.

One might notice that the shares of low-quality and high-quality wood products are applied to the gross final wood harvest even though their shares refer to the net wood harvest. This can be seen as an inconsistency; however, the SOFI is meant to be an indicator. The 
conversion of gross wood harvest to net wood harvest would be necessary only if the conversion rate of the forest types and site classes were significantly different. This type of modification is possible depending on the purpose and area of the application.

Selecting the market price source of the representative wood products requires careful consideration. It is of paramount importance to avoid the effects of short-term price volatility that would distort the comparability of forest types. Wood products tend to show constant prices relative to each other (Rumpf et al. 2015); however, this is only true on longer time horizons. There are well established economic survey networks aiming at surveying incomes and costs at forest holdings (Schiberna et al. 2011, Sekot 2017). In these cases, prices need to be calculated to the same delivery point (e.g. in the forest or delivered to factory etc.) before they are used to calculate the mean values.

The calculations exclude production costs. Through the incorporation of production costs, a profitability index could be created, one which would give a more precise indicator of the financial potential of forests. Nevertheless, costs are much more uncertain than incomes. Some of the costs depend on natural circumstances, such as the terrain as well as type of forest and site. Other costs are influenced by local economic conditions such as transport infrastructure, market accessibility, the labour market, and other resources as well as forest manager choices and legal restrictions. These factors make cost estimations uncertain enough to divert the index from its original purpose of remaining simple and of representing forest and site combinations rather than regional economies.

It is worth repeating that the SOFI can be further adapted to the purpose of its application and to data availability, and extended with the major cost items similarly to eq.5, which considers reforestation as a crucial cost.

$$
\mathrm{SOF}_{x}=\frac{\left[S V_{L Q x} \cdot \mathrm{LQ} \%_{x}+S V_{H Q x}\left(1-\mathrm{LQ} \%_{x}\right)\right] \mathrm{Q}_{x} \cdot(1-C \%)}{\mathrm{R}_{x}}
$$

Where symbols are the same as at eq.1, except:

C\%: Share of reforestation costs to output value of final harvest

Output potential approximations become more accurate with larger aggregation areas and forests that fit the definition of a normal forest. The current state of a forest does not influence the result as its tree species composition is the basis of calculation, but its stocking, health, and other properties are not considered.

The greatest advantage of the SOFI is the ability to compare various tree species, and the effect of the quality premium of wood products. Although the calculation is primarily based on yield tables, which are constructed for even-aged forests, eq.2 shows that if MAI is available for uneven-aged forests, these can also be covered. In this case, MAI should refer to mature trees only, in the same manner that only the final harvest is considered for even-aged forests.

Similar to the case study below, indexing the SOFI is unnecessary if it is used in calculations. The idea behind choosing a reference forest type is that in long time series the nominal values of the SOFI need further processing to be comparable (because of price inflation for instance). Furthermore, when the SOFI is used to present the suitability of forest for wood production, it is easier to demonstrate in comparison to a frequently occurring forest type than with an indicator with an abstract meaning. 


\section{DEMONSTRATION OF APPLICATION}

In an attempt to demonstrate the applicability of the SOFI and its ability to represent the financial potential of a forest, a simple case study is presented here. The hypothesis of this study is that the income from the forest is strongly correlated with the potential output, which can be described with the SOFI replacing detailed modelling.

There is no common time period for which all data necessary for the calculations would be available; therefore the following sources were used:

- National Forest Database from 2012, which contains tree species distribution and site classes at the forest plot level, and the geographical location of the plot (NFD 2012)

- Yield tables for the forest species groups (Béky 1981, Béky 1983, Kovács 1983, Kiss et al. 1985, Solymos 1993, Keserü - Rédei 2012, Keserü et al. 2017, Rédei et al. 2019)

- National Statistical Program annual survey on forest products 2010-2015

- National Statistical Program annual survey on wood product prices 2018

- Wood product price-surveys of the NARIC Forest Research Institute 2013-2018.

In Hungary, there are 22 state-owned forest companies covering the whole country. Excluding those which have woodworking branches, or which do not cover an entire county, 12 can be used as samples and be compared to the SOFI value of the respective county.

The SOFI is calculated for tree species groups divided into six site classes. The reference forest type is Turkey oak (Quercus cerris) third site class, which provides a relatively high MAI, but does not comply with higher quality standards due to the low level of wood resistivity.

Forest companies disclose their incomes publicly in their annual financial reports. For this demonstration, their mean annual income per hectare from 2010-2014 is used. Figure 1 shows that the company income per hectare is strongly correlated $\left(R^{2}=0.85\right)$ with the SOFI of the respective county.

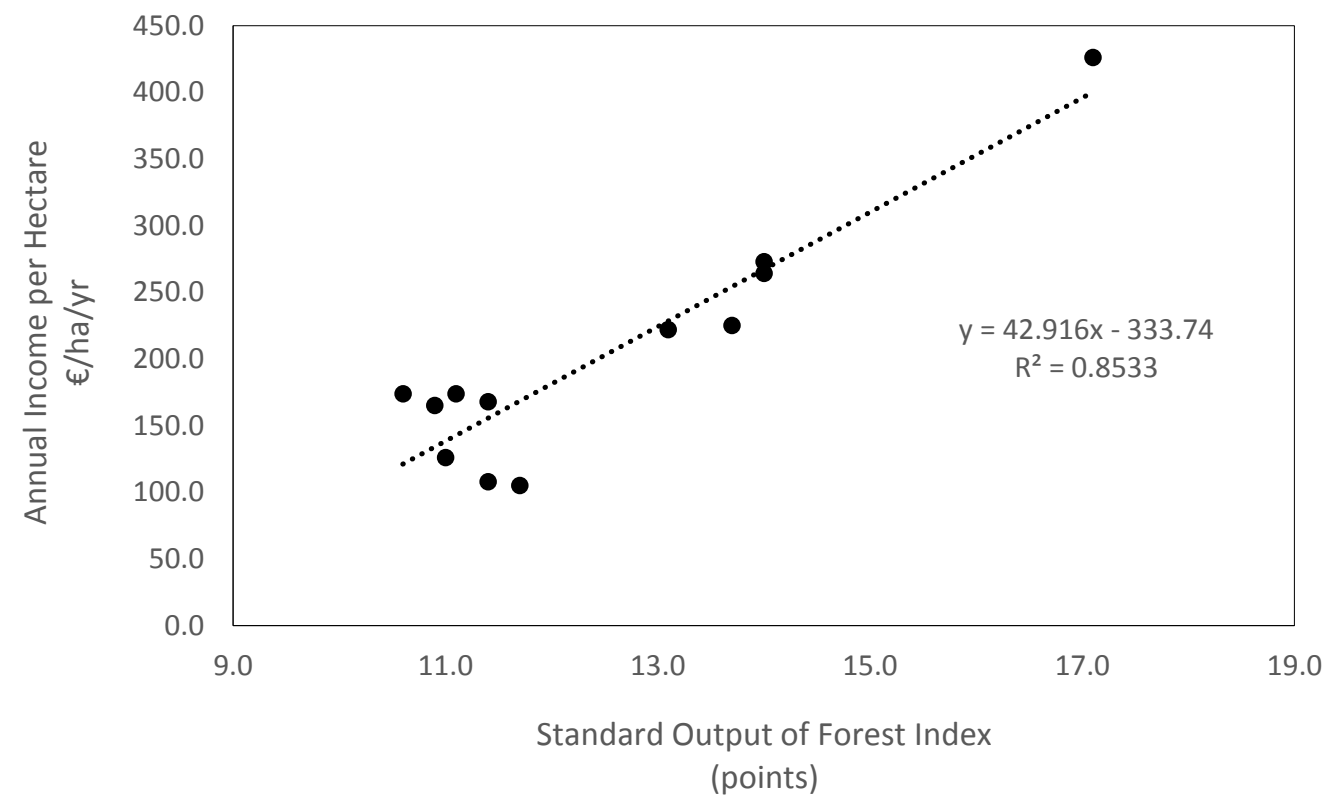

Figure 1. Relationship of the annual income per hectare ( $€ /$ ha/yr) of selected forest companies and the Standard Output of Forest Index of the counties where their forests are located

(Currency rate: 333 HUF/EUR) 


\section{CONCLUSIONS}

If the potential financial performance of a defined forest area is to be described, the SOFI can be used efficiently by reducing the necessary input data and modelling. The need for such reduction arises from the unavailability of detailed reliable data, while the sophisticated modelling of the various forest types and management regimes would complicate the analysis without increasing its accuracy proportionally. The original form of the SOFI can be used in analyses that include economic comparisons across forest types or forests of various geographical regions. Its major benefit is its slim construction, for which comparable input data can be easily obtained, and the same methodology can be applied on a large geographical scale. It can be further refined for specific purposes. Examples for such modifications have been presented in this paper. However, further elaboration requires additional input data, which eliminates the SOFI's advantages.

\section{REFERENCES}

BAUR, F. (1881): Die Rotbuche in Bezug auf Ertrag, Zuwachs und Form. Verlag von Paul Parey, Berlin

BÉKY, A. (1981): Mag eredetü kocsánytalantölgyesek fatermése [Yield table of pedunculate oak of seedling origin]. Erdészeti kutatások 74: 309-320 (in Hungarian)

BÉKY, A. (1983): Országos fatermési tábla gyerty.ánállományokra [Yield table of hornbeam]. Erdészeti kutatások 75: 199-207. (in Hungarian)

BELJAN, K. - POSAVEC, S. - CAVLOVIC, J. - TESLAK, K. - KNOKE, T. (2018): Economic consequences of different management approaches to even-aged silver fir forests. Croatian Journal of Forest Engineering 39 (2): 299-312.

Cséki, P. - Kalicz, P. - Brolly, G. B. - CsóKA, G. - Czimber, K. - GribovszKi, Z. (2014): Hydrological impacts of various land cover types in the context of climate change for Zala County. Acta Silv. Lign. Hung. 10: 115-129. https://doi.org/10.2478/aslh-2014-0009

Hartebrodt, C. - Holthausen, N. - BitZ, S. (2007): Insurance solutions as a part of risk management in forest enterprises. Allgemenine Forst und Jagd Zeitung 178 (5-6): 98-108.

KESERÜ, ZS. - RÉDEI, K. (2012): Homoki Leuce-nyárak termesztési technológiai modelljei [Tending operation models for leuce-poplars under sandy soil conditions] Erdészettudományi közlemények 2 (1): 61-71. (in Hungarian)

KESERÜ, Zs. - CSIHA, I. - KOVÁCS, Cs. - RÁSÓ, J. - RÉDEI, K. (2017): Vörös tölgyesek természetes felújítása és erdőnevelése: esettanulmányok [Silviculture and natural regeneration of red oak: a case study]. Erdészettudományi Közlemények 7 (2): 115-125. (in Hungarian) https://doi.org/10.17164/EK.2017.008

KilHAM, P. - HARTEBRODT, C. - SCRAML, U. (2016): A conceptual model for private forest owners' harvest decisions: A qualitative study in south west Germany. Forest Policy and Economics 106, UNSP 101971. https://doi.org/10.1016/j.forpol.2019.101971

KISS, R. - SOMOGYI, Z. - JUHÁSZ, G. (1986): Kocsányos tölgyfatermési tábla [Yield table for sessile oak]. Erdészeti kutatások 78: 265-282. (in Hungarian)

KovÁCs, F. (1983): A csertölgyállományok fatermése [Yield table for Turkey oak]. Erdészeti kutatások 75: 179-188. (in Hungarian)

LAMOLM, S. - SAVIDGE R.A. (2003): A reassessment of carbon content in wood: variation within and between 41 North American species. Biomass and Bioengineering 25: 381-388. https://doi.org/10.1016/S0961-9534(03)00033-3

MacDicken, K. G.-Sola, P.-Hall, J.E.-Sabogal, C.-TAdoum, M.-De WaAeige, C. (2015): Global progress toward sustainable forest management. Forest Ecology and Management 352: 47-56. https://doi.org/10.1016/j.foreco.2015.02.005

MÁtyÁs, Cs. - Berki, I. - Bidló, A. - CSÓKA, Gy. - CZimer K. - FÜHRER E. - GÁlos B., GribovsZKI, Z. - ILlÉS, G. - HiRKA, A. - SOMOGYI Z. (2018): Sustainability of Forest Cover 
under Climate Change on the Temperate-Continental Xeric Limits. Forests 9 (8): 489. https://doi.org/10.3390/f9080489

MoricZ, N. - TÓTH, T. - BALOG, K. - SZABO, A. - RASZTOVITS, E. - GRIBOVSZKI, Z. (2016): Groundwater uptake of forest and agricultural land covers in regions of recharge and discharge. iForest-Biogeosciences and Forestry 9 (5): 696-701. https://doi.org/10.3832/ifor1864-009

NFD (2012): National Forest Database. National Land Centre, Hungary. Accessed: 2012.01.01.

PANDEY, S.S. - SUBEDI, B.P. - DHUNGANA, H. (2010): Economic potential of forest resource of Nepal. Banko Janakari 20 (2): 48-52. https://doi.org/10.3126/banko.v20i2.4803

POSAVEC, S. - KAJBA, D. - BELJAN, K. - BORIC, D. (2017): Economic analysis of short rotation coppice investment: Croatian case study. Austrian Journal of Forest Science 1: 163-176.

Pretzsch, H. - Biber, P. - SChÜtze, G. - Uhl, E. - RÖTZER, T. (2014): Forest stand growth dynamics in Central Europe have accelerated since 1870. Nature Communications 5: 4967 http://doi.org/10.1038/ncomms5967

RÉDEI, K. - KESERÜ, ZS. - RÁSÓ, J. - GÁL, J. (2019): The effects of thinnings on yield and value changes in black bocust (Robinia pseudoacacia L.) stands: A case study. Acta Silv. Lign. Hung. 15 (1): 47-52. https://doi.org/10.2478/aslh-2019-0004

RuMPF, J. - HORVÁT, A.L. - SZAKÁlosnÉ MÁTYÁs, K. (2015): Egyes fák és faállományok minőségi osztályai és fahasználati árbevételi kategóriái [Tree utilization price revenue ctegories and quality classification of some tree and forest stands]. Erdészettudományi Közlemények 5 (1): 21-41. (in Hungarian) https://doi.org/10.17164/EK.2015.002

SEKOT, W. - Fillbrandt, T. - Zesinger, A. (2011): Improving the International Compatibility of Accountancy Data: The 'DACH-Initiative'. Small-scale Forestry 10 (2): 255-269. https://doi.org/10.1007/s11842-010-9134-y

SEKOT, W. (2017): Forest Accountancy Data Networks as a Means for Investigating Small-Scale Forestry: A European Perspective. Small-scale Forestry 16: 435-449. https://doi.org/10.1007/s11842-017-9371-4

SISAK, L. - RIEDL, M. - DUDIK, R. (2016): Non-market non-timber forest products in the Czech Republic-Their socio-economic effects and trends in forest land use. Land Use Policy 50: 390398. https://doi.org/10.1016/j.landusepol.2015.10.006

SKOVSGAARD, J.P. - VANCLAY, J.K. (2008): Forest site productivity: a review of the evolution of dendrometric concepts for even-aged stands. Forestry 81: 13-31. https://doi.org/10.1093/forestry/cpm041

Schiberna E. - LetT B. - HÉJJ B. (2011): The Economic Monitoring Network for Private Forests in Hungary. Small-Scale Forestry 10 (2): 245-253. https://doi.org/10.1007/s11842-010-9144-9

SOLYMOS, R. (1993): Új fatermési táblák erdeifenyőre [New yield table for Scots pine]. Erdészeti kutatások 82-83: 357-382. (in Hungarian)

SOMOGYI, Z. (2008): Recent trends of tree growth in relation to climate change in Hungary. Acta Silv. Lign. Hung. 4: 17-27.

Vrolijk, H. - Poppe, K. - KeszThelyi, Sz. (2016): Collecting sustainability data in different organisational settings of the European Farm Accountancy Data Network. Studies in Agricultural Economics 118 (3): 138-144. https://doi.org/10.7896/j.1626 